\title{
The Leading Impact of the Application of Nanotechnology on Reducing the Expected Production Costs in the Jordanian Industrial Companies
}

\author{
Osama Abdulmunim Ali ${ }^{1}$ \\ ${ }^{1}$ Associate professor, Department of Accounting, Jerash University, Jordan \\ Correspondence: Osama Abdulmunim Ali, Associate professor, Department of Accounting, Jerash University, \\ Jordan.
}

Received: November 22, 2018

Accepted: December 18, 2018 Online Published: December 21, 2018

doi:10.5539/ibr.v12n1p73

URL: https://doi.org/10.5539/ibr.v12n1p73

\begin{abstract}
Nanotechnology and nanomaterials are some of the most important modern concepts that when economic units enter into production, they will offer products with features that are superior to those produced in a traditional costing manner. Given the scientific progress and technological development that have led to increased competition, the industrial companies need to Apply concepts that help introduce nanomaterials into production and reap the benefits ,Therefore, This study aimed to find the leading impact of the application of Nanotechnology on reducing production costs in Jordanian industrial companies.

The sampling unit in this study consists of the financial managers and cost managers of the listed industrial companies In Amman Financial Market, where the number of financial directors and cost managers of industrial companies was (105), and (80) questionnaires have been distributed to companies, (75) questionnaires were retrieved , (5) questionnaires were incomplete, thus the number of questionnaires recovered and were ready for analysis were (70) questionnaires, The most important result of the study was the impact of the application of nanotechnology dimensions combined on reducing costs in the Jordanian industrial companies, while the most important recommendation of the study was the need of Jordanian industrial companies management's commitment to the moral values Of Nanotechnology to reach local and global industrial leadership. With the need of them to recognize the importance of the workforce in the deployment and adaptation of Nanotechnology to reach a global industry level. .
\end{abstract}

Keywords: nanotechnology, reduced production costs

\section{Introduction}

The historical development of managerial accounting is linked to economic conditions, technical developments, and the development of business organizations and administrative thought in general. At each stage of its development, management accounting used various means and tools to meet the different requirements and needs of all parties involved, as it contributed to supporting administrative decisions in all fields .In the last three decades, as a result of the rapid development in business organizations and industrial companies and their needs, traditional methods of management accounting have been criticized for neglecting the strategic requirements of business organizations and the leading companies and how the traditional methods emphasis on traditional aspects of oversight and performance evaluation of the operational aspects of the organizations and the companies. The need for the development of accounting tools and techniques and the need for it to be available in the form and to the extent which the Department needs to face its growing problems and help to make appropriate decisions in a timely manner has become increasingly necessary.In response to these criticisms, researchers and professionals have developed many tools and techniques that are consistent with the consolidation of the strategic directions of management accounting. These include the introduction of nanotechnology, which is the link between management accounting and strategic management because of its importance during a time of competitiveness amongst industrial organizations and companies which are aspiring to global leadership.

\subsection{The Importance of the Study}

This study derives its importance from the rapid developments in business organizations and industrial companies, 
and the need of managers and decision makers to have efficient accounting systems that provide them with appropriate information to support their decisions. The importance of theoretical and practical study is highlighted as follows

\subsubsection{The Theoretical Importance}

The study theoretical importance is represented as it seeks to define the conceptual framework of the concept of nanotechnology as a basic requirement to meet management needs and contribute to the development of the strategic directions of industrial companies and identify their role in reducing costs at the company level.

\subsubsection{Practical Importance}

In terms of practicality, the importance of the study is that it deals with the nanotechnology, which was created in order to cope with the huge development in the business organizations and the environment of manufacturing as well as the fierce competition that swept the markets locally and globally, which was one of the most important motives that made the idea of cost reduction a major requirement For industrial companies in modern times. The study also seeks to measure the response of industrial companies in Jordan to this technology and to show their effect in reducing production costs in the public joint stock companies listed on the Amman Stock Exchange.

\subsection{The Problem of the Study and Its Questions}

The problem of the study arises because many business organizations and companies follow traditional cost management systems, and because these systems are unable to meet the requirements of the economic environment and business organizations and companies, as a result of the large size of companies and the complexity of organizational structures and the rapid technological developments and the increasing competition between companies. Therefore, the companies had to look for new ways to reduce costs. One of these methods is known as Nanotechnology, so the questions of the study problem are:

- The main problem's question: Is there a statistically significant impact of the application of Nanotechnology on reducing production costs in Jordanian industrial companies?

And following it, sub questions arises:

- first problem's question: Is there a trace of preparing qualified workforce to reduce production costs in the Jordanian industrial companies?

- second problem's question: Is there a trace of the presence of distinguished leaders to reduce production costs in the Jordanian industrial companies?

- third problem's question :Is there a Trace of prevailing cultural knowledge and achievements on the reduction of production costs in the Jordanian industrial companies?

- fourth problem's question: Is there an effect to the formation of supporting organizations in reducing production costs in the Jordanian industrial companies?

- fifth problem's question: Is there a trace of re-engineering of companies in reducing the production costs in the Jordanian industrial companies?

\subsection{Hypotheses}

Based on the problems questions, the hypotheses focused on:

- main study hypothesis H0: there are no statistically significant effect of the application of Nanotechnology in reducing production costs in industrial companies,

and its sub-hypotheses are:

- first hypothesis H01:There are no traces of preparing qualified workforce to reduce production costs in Jordanian industrial companies

- second hypothesis H02: There is no presence of distinguished leaders to reduce production costs in the Jordanian industrial companies

- third hypothesis H03: There are no traces of prevailing cultural knowledge and achievements on the reduction of production costs in the Jordanian industrial companies

- fourth hypothesis H04:There are no effects to the formation of supporting organizations in reducing production costs in the Jordanian industrial companies

- fifth hypothesis H05:There are no traces of the re-engineering of companies on reducing the production costs in the Jordanian industrial companies 


\subsection{Study Sample}

The study sample is the financial managers and directors of costs in public shareholding industrial companies listed in Amman Financial market, and their number in industrial companies (105) Financial Manager and Director, (80 ) questionnaires have been distributed to companies according to Sekaran statistical table, (75) questionnaires were retrieved, (5) of which were incomplete and were excluded from the analysis. Thus, the number of retrieved and verifiable responses is 70 and with $87.5 \%$ retrieval percentage, which is statistically acceptable.

Statistical methods used:

The Statistical Package for Social Sciences (SPSS) was used in the following statistical analyzes:

1. Descriptive Statistics: Frequency, percentages, arithmetic averages and standard deviations were used to provide a comprehensive description of the degree of approval of the sample members of the study sample.

2. The Cronbach Alpha consistency coefficient for measuring the stability of the study instrument, which is the questionnaire

\section{Simple linear regression analysis}

4. Multiple Linear Regression analysis

\section{Stepwise regression analysis}

6. The relative importance is determined according to the following formula and according to the five-measure of the alternatives for each paragraph

Where the number of levels are: low, medium, high, thus:

Low level if the arithmetic mean reaches 1.00 to less than 2.33

The average level if the mean is 2.33 to less than 3.66

The high level if the arithmetic mean from 3.66 to 5.00

\section{Theoretical Aspect}

\subsection{The Intellectual Dimension of Nanotechnology}

First of all, it is necessary to know the intellectual significance of the word nano. It is an expression originally derived from the Greek word nano (dwarf) or the finite or small thing, a scale equivalent to one millionth of a millimeter and one billionth of a meter Which is equivalent to one in ten thousand thickness of human hair and this unit is used to express the dimensions and diameters and measurements of atoms and molecules of substances, compounds, cells and micro-particles such as bacteria and viruses. Nanotechnology is a scientific application that produces things by assembling them at the micro level of its basic components such as atoms and molecules. As long as all the materials of the atoms are aligned according to a certain structure, we can replace the atoms of an element with another atom. It is something that sometimes surprises us with new features that we did not know before, opening up new areas to benefit the human being at the lowest possible cost. (MHS Ahmeda et al., 2017).

Nanotechnology is therefore a set of tools, techniques and applications that relate to the manufacturing and installation of a particular structure using very small scales or a science that deals with the research and development of modern objects and methods that are located within the nanometer scale, It is a scientific application that produces objects by assembling them from their basic components such as atom and molecule, or it is the complete and precise control in the production of materials by controlling the interaction of the molecules involved in the reaction and directing these molecules to the production of a particular material. This type of reaction is known as molecular processing which is putting the atoms during the reaction in their proper place. (Catharine Paddock, 2012)

Therefore we find that (Sharif 2010) defined it as this advanced technology based on understanding and studying nanotechnology and other basic science in a rational and creative way with the technological ability of synthesizing nanomaterials and controlling the internal structure by restructuring and arranging atoms and molecules and their constituent to ensure having unique products which can be employed in different applications.

(Al-Maghribi) has defined it as a scientific application to produce things by assembling them at the small level of their basic components such as atom and molecule.

also each of ( Rajiv Saini et al., 2010) indicated that Nanotechnology can be defined as the science and engineering involved in the design and the compatibility, it is the precise description of product parts and the use of materials and devices in applications to reach its smallest functional organization, at least one dimension on a nanometer or 
one billionth of a meter. In these measurements, the consideration of individual molecules and interacting groups of molecules with respect to the broad microscopic properties of materials or devices becomes important, as they have control over the basic molecular structure, which allows for control of the chemical and physical properties of the nanoparticles. Nanotechnology has found many applications in medicine and other Important areas of life.

The researcher agrees with both ((Priya Satalkar et al). That There is no agreement on the definition of nanotechnology, and this stems from fundamental debate about identifying "nanotechnology." which shows the leading intellectual movement for this definition at a local and global level

\subsection{The Ability of Nanotechnology in Improving the Structure of Materials in Manufacturing and Production} Processes

Nanotechnology has the ability to improve the structure and performance of the materials in which it is manufactured from, and as known, as an item gets smaller its measuring will be improved and precis. Therefore, the applications of nanotechnology in the manufacturing process require three steps. The first step, used in the 1990s, was to investigate the ability to manipulate atoms, and to keep them in the required positions. And the possibility of this ability to produce elements that Do not include scrap with effective and almost perfect accuracy. The second step is to produce assembly devices that can be programmed to influence atoms and molecules. The compilers will have a sub-microcomputer arm controlled by computers. This strategy will produce assemblies in Nanotechnology level, get rid of the atoms in its proper place. Finally, the last third step would be to create enough complexes to produce consumer goods. This will be achieved by using replicas - complexes that are programmed to create additional complexes. (Maria Benelmekki, 2015))

\subsection{Economic Importance of Nanotechnology}

Nanotechnology is leading a new industrial revolution that is reshaping the economies of the different countries of the world, creating labor markets and developing international trade, the relations of the countries of the world, and undoubtedly the different social and economic changes, and nanotechnology which is based on restructuring the atomic structure and reduce their molecules and granules to create new materials called nanomaterials which will create a clear impact on the countries of the world, especially, the countries which still rely on a few basic commodities and labor revenues and export revenues, the application of nanotechnology which is connected with the manufacturing of goods that are considered as the core of The interest of nanotechnology associated with patents which will lead to the replacement of manufactured products with natural products, which will affect the economies of different countries of the world and the export of these commodities and materials.Nanotechnology is effective in the development of the economies of the world when it is adapted to the local, social ,and institutional context if it was chosen and designed through the development of sound strategies to integrate the absorption, acquisition and diffusion of knowledge, despite the different costs of entering the world of nanotechnology from one country to another.) (NajmDin and Al bermana (.2016 Maria Benelmekki, 2015))

\subsection{Pioneering Nanotechnology Effect on Productions Costs}

both Darby and Zucker (2003) Bowers and Cernac (2008) stated that nanotechnology will lead to a rapid improvement in the production process. Where it is expected to reduce unit cost of the products through the most effective use of inputs. In the same way, West (2008) is expected to produce many kinds of products quickly, such as printers and computers that can prepare many copies of data as small-cost files. West (2008) added that nanotechnology would make products as cheap as copying files. However, this is expected to happen in the future because nanotechnology products can be produced at a reasonable cost and will deliver electricity at a higher rate than is possible now. For this reason, nanotechnology is seen as the next industrial revolution and it is expected to play a key role in achieving a key function across the full value chain of the product. Reekerby and Morrison (2007) stated that this effect will be achieved through the valuable properties of nanotubes embedded in a small percentage of the final device, or through processes and applications that support nanotechnology without the need for end products containing any nanomaterials. This effect of nanotechnology on the value chain of products will result in the production of high quality products at a very low cost, on the other hand using and improving nanotechnology will quickly allow the creation of new nanoparticles in the same properties. Nanoscale factories will reduce many types of costs by reducing direct labor inputs or eliminating distribution, shipping, storage and other related costs. and according to traditional technology 80 to 90 percent is the usual of the total costs associated with the early phases of the product life cycle.

\section{The Concept of Cost Reduction and Its Relationship to NANO}

cost reduction is defined as achieving the lowest level of costs compared to the previous level, such as the use of machines and equipment that perform the same processes at lower costs or maximize production quantities with 
the same value of costs, access to materials and products at lower costs than before, and making a Change and modifying work policies, practices and to reduce waste of time or reduce overtime costs (Arnold \& Chapman, 2008).

This process is the highest priority for companies because of its impact on the revenues and profits of the company and to ensure its growth and continuity. The aim of this process is to follow a series of methods, policies and practices derived from the company's reality, environment and nature. Especially those in the accountability position (Goetsch \& davis, 2006).

The methods and strategies that reduce the cost which are used by the company vary in cost, the most protruding ones are (Erekat, 2015, 26):

1. speed in delivery.

2. Limit wasting time, effort and money.

3. Stability of activities, functions and business.

4. Perform the work properly and free of errors and deviations.

5. Efficiency and effectiveness in work and strength and robustness of organization and accuracy.

6. Utilize the equipment with the highest tolerances, quality, ease of use, repair and maintenance.

The cost reduction process is subjected to two inputs: First, the traditional approach, which is a standard control system aimed at detecting and determining the causes of standard deviations (Rahamna, 2011). Second, the modern approach, which came in response to the increasing awareness of the customers of the products provided by companies, and the desire to provide their needs and meet their requirements and satisfy their desires to obtain products of high quality and appropriate qualities and low price at the same time, where companies resorted to adopting a variety of methods that will Check this response. This approach is seen as a method of reducing costs as one of the methods that leads to lower prices of products without compromising their basic qualities to reach customer satisfaction and to meet their demands (Horngren et al., 2016, 219), which aims to reduce the costs of labor activities and costs Products without any change in their quality, characteristics and functions (Rajkhan, 2002). To achieve this goal, companies have used several systems, most notably: target cost, activity-based costs, and process reengineering.

\subsection{Targeted Cost System}

The cost system is considered a cost-management approach designed primarily to reduce product costs during the pre-production phase, without compromising its quality and maintaining its functional potential (Foda, 2007, 209). Through this procedure Data and information that allows for the decision to start or stop the production process are being produced. The cost-goal role is to reduce costs by refuting the cost-to-molecules target and abandoning unnecessary parts (Buckley, 2008, 162).

\subsection{Activity Based Costs}

The activity -based cost system is considered one of the cost information systems (Ashmawi, 2011, 286) and is directed to allocate costs to cost targets (Horngren et al., 2016, 146). Its role is to reduce costs in two phases: First: the design phase, where this tool adjusts and controls the resources in the production process. Second: the production stage, which reduces the level of inventory and the time required to deliver and respond to customer requirements (Iron, 2006, 37). In both phases, the system performs its work in the light of the detailed information that highlights the way in which the production stages are carried out by allocating costs to the products and the post-production phase by providing reports on the contribution of the manufactured products and the customer's view of them, The distribution of profits and the use of resources and capabilities, and this information can help the management take various decisions that concern the production process from the production stage to the stage of after-sale services (Saleh, 2012, 305).

\subsection{Reengineering the Processes}

Reengineering the Processes is a modern method of reducing the cost of production. The role of this method is to reduce the costs of activities and processes and to reduce non-host activities and processes by redesigning the implementation, (Erekat, 2015, 27). Where this method is based on the following (Soliman et al., 2012, 355): First: identifying the activities of the operations required to perform each specific production process and then classifying them into groups that include simple steps and a simple process of implementation of the production process, which makes it easier to track and identify the things that do not add value to the products and the process and thus predict the actual time it takes to perform the work. 
Second: To analyze the value of the activities of the operations and the steps of the work and classify them into groups, which makes it easier to study and determine the amount of cost and resources and the potential used in them.

Third: Analysis of the flow of operations' activities within departments and organizational units within the company, which facilitates the process of determining the time taken to perform the steps and stages of that process and steps that do not add value. Fourth, determine responsibility centers by identifying the costs of activities, processes and activation of accounting responsibility and participation of workers in the application of re-engineering procedures.

The company's application of this method leads to customer satisfaction, providing the appropriate climate to ensure its growth and sustainability. This method is applied by a decision issued by the company's management. The decision is subject to several factors: cost, by comparing the costs of applying the process re-engineering to the costs of maintenance, modernization and development and the creation of a new system. Time, by specifying the time the process of reengineering takes $t$, and the life span of that process. Risk, by identifying the effects generated by the re-engineering process and its associated price inflation. And finally the benefits, by identifying the benefits that the company derives from its application of the reengineering process (Aziz, 2006, 65).

Here the researcher agrees with Cooper (1988)That the use of advanced techniques in the production process will result in greater changes in the variable or fixed cost rate. Cost structure changes also include direct labor costs that are replaced by indirect costs or overhead costs that require the proper allocation of products and services, although Cooper (1988), Fadzil and Rababah (2012) demonstrated that the use of new technology in the production process would result in Increasing the fixed cost rate and reduce the variable cost rate in the product unit. They add that the profit margin and net profit of the product unit produced by the new technology will also increase, because the total costs will be reduced using more efficient technology. Researchers such as Bowers and Cernac (2008) reported that the use of nanotechnology would reduce the cost of products, and this will explain the application of this technology at the local and global levels.

Therefore, the researcher believes that the integration of new nanomaterials in production lines as a result of the use of cost systems will lead to improved technological performance in production and the introduction of new product functions within industrial companies because the introduction of these new nanomaterials into production will need controlled conditions and correct control to be created and maintained in industrial processes. The use of new nanomaterials in production also contributes to having improved control and to reaping benefits gained from the use of nanomaterials in industrial processes. In addition to increasing the durability of these industrial processes, and Improving and evaluating the production line performance in terms of productivity and cost efficiency; to improve the functionality and performance of product installation within industrial companies . .

\section{Practical Aspect}

\subsection{The Characteristics of the Study Sample}

In order to describe the characteristics of the study sample, the frequency and percentages of the demographic variables were found for the sample of the study as follows:

\subsubsection{Age}

Table 1. Distribution of sample members by age variable

\begin{tabular}{llll}
\hline percentage & Category & Repetition & variable \\
\hline 35.7 & Less than 30 years & 25 & \\
50.0 & 30. Less than 40 years & 35 & Age \\
14.3 & 40. Less than 50 & 10 & \\
0.0 & 50 years and over & 0 & \\
35.7 & Total & $\mathbf{7 0}$ & \\
\hline
\end{tabular}

Table (1) shows that the age group (50 years and over) is the lowest category $(0.0 \%)$ while the age group (30 less than 40 years) is the largest $(50.0 \%)$,

Followed by a category (less than 30 years), indicating that financial managers and cost managers are concentrated in the youth category. 


\subsubsection{Scientific Qualification}

Table 2. Distribution of sample members according to the variable of scientific qualification

\begin{tabular}{llll}
\hline Frequency & percentage & Category & variable \\
64 & 91.4 & BA & Scientific \\
6 & 8.6 & Postgraduate & qualification \\
\hline $\mathbf{7 0}$ & $\mathbf{1 0 0}$ & Total & \\
\hline
\end{tabular}

From the table, it is clear that the holders of the Bachelor's degree form the majority of the sample, reaching $53.6 \%$.

\subsubsection{Years of experience}

Table 3. Distribution of sample members by years of experience

\begin{tabular}{|c|c|c|c|}
\hline Frequency & percentage & Category & variable \\
\hline 8.6 & 6 & Less than 5 years & \\
\hline 48.6 & 34 & $\begin{array}{l}\text { From } 5 \text { - Less than } 10 \\
\text { years }\end{array}$ & \\
\hline 28.6 & 20 & $\begin{array}{l}\text { From } 10 \text { - less than } 15 \\
\text { years }\end{array}$ & Years of experience \\
\hline 14.3 & 10 & More than 15 years & \\
\hline 100 & 70 & total & \\
\hline
\end{tabular}

The table shows that the respondents have relatively high practical experience. The percentage of the category of expertise (less than 5 years) was the lowest $(8.6 \%$ ), while the rest of the groups were at a higher rate. , Which indicates that industrial companies retain high experience.

\subsubsection{Career Status}

Table 4. Distribution of sample members by the Career status variable

\begin{tabular}{llll}
\hline Frequency & percentage & $\begin{array}{l}\text { Category variable } \\
\text { Head of the } \\
\text { Department }\end{array}$ \\
6 & 84.3 & $\begin{array}{l}\text { Director of the Career status } \\
\text { Department } \\
\text { General Manager / } \\
\text { Deputy Director } \\
\text { Total }\end{array}$ \\
\hline $\mathbf{7 0}$ & 7.6 & $\mathbf{1 0 0}$ & \\
\hline
\end{tabular}

The table shows that the majority of the sample (84.3\%) was category (head of department), while the other administrative groups that performed the financial work and costs constituted the rest of the sample. This indicates that the majority of industrial companies have financial departments and sections of costs separate from the general management of the company.

\subsubsection{Specialization}

Table 5. Distribution of sample members by specialization variable

\begin{tabular}{llll}
\hline Frequency & percentage & Category & variable \\
52 & 74.3 & Accounting & \\
0 & 0.0 & Business Administration & \\
1 & 1.4 & Economies & \\
17 & 24.3 & Banking and Financial Specialization \\
$\mathbf{7 0}$ & $\mathbf{1 0 0}$ & Sciences & \\
\hline
\end{tabular}

We note from the table (5) that category (accountants), formed the largest percentage (74.3\%), this corresponds to the nature of the work of the Financial Chief Officer and Director of the cost, which requires full knowledge of the accounting procedures necessary to carry out the tasks of accounting and duties of each of them.

\section{The Reliability and Honesty of the Study Instruments}

The stability of the instrument used to measure the variables used was tested using the Cronbach Alpha Coefficient test, where the result of the scale is statistically acceptable if the value of Cronbach alpha is greater than 0.60 (Sekaran, 2003). The closer the value is to $100 \%$ it was considered as an indicative of the higher stability of the study instrument, and given the data in Table (6), the Cronbach Alpha Coefficient of consistency was measured for the study variables, their dimensions and the study instrument as a whole to determine the consistency of the responses as follows: 
Table 6. Internal consistency coefficient values for the study tool paragraphs

\begin{tabular}{lll}
\hline Alpha value & The dimension & NO \\
\hline $\mathbf{0 . 7 5 5}$ & Prepare a qualified workforce & $\mathbf{1}$ \\
$\mathbf{0 . 7 8 6}$ & The presence of distinguished leaders & $\mathbf{2}$ \\
$\mathbf{0 . 7 8 0}$ & The culture of knowledge and achievement & $\mathbf{3}$ \\
$\mathbf{0 . 8 2 4}$ & Formation of Supporting Organizations & $\mathbf{4}$ \\
$\mathbf{0 . 7 6 1}$ & Corporate reengineering & $\mathbf{5}$ \\
$\mathbf{0 . 8 4 7}$ & Nanotechnology & $\mathbf{6}$ \\
$\mathbf{0 . 7 5 3}$ & Reduce production costs & $\mathbf{7}$ \\
$\mathbf{0 . 8 3 9}$ & All paragraphs & $\mathbf{8}$ \\
\hline
\end{tabular}

We Note that the values of the Cronbach alpha coefficient of the study instrument ranged from (0.755 to 0.847$)$, the coefficient value for all the paragraphs $(0.839)$ and therefore all the values are greater than 0.60 . This indicates the consistency between the sections of the study instrument, the reliability of the study tool and the possibility to Rely on them for statistical analysis.

\section{Analysis of the Responses of the Sample Members of the Study}

The responses of the sample members were presented using descriptive statistics. The mean, standard deviations, rank, and relative importance were calculated.

First: Nano technology, including:

\subsection{Prepare a Qualified Workforce}

Table 7. The arithmetical averages, the standard deviations and the relative importance of the paragraphs of the preparation of a qualified force

\begin{tabular}{|c|c|c|c|c|c|}
\hline $\begin{array}{l}\text { Arithmetic } \\
\text { mean }\end{array}$ & $\begin{array}{l}\text { standard } \\
\text { deviation }\end{array}$ & Rank & $\begin{array}{l}\text { relative } \\
\text { importance }\end{array}$ & Paragraph & NO \\
\hline 4.045 & 0.745 & 1 & High & $\begin{array}{l}\text { The company's management and decision makers recognize } \\
\text { the importance of the workforce in deploying and adapting } \\
\text { nanotechnology. }\end{array}$ & 1 \\
\hline 3.918 & 0.766 & 3 & High & $\begin{array}{l}\text { The company has a database of its workforce and all those } \\
\text { who are familiar with nanotechnology and science }\end{array}$ & 2 \\
\hline 3.881 & 0.776 & 5 & High & $\begin{array}{l}\text { The company holds educational programs and training } \\
\text { workshops in coordination between industry, education and } \\
\text { research centers in order to learn about and benefit from the } \\
\text { programs of developed countries. }\end{array}$ & 3 \\
\hline 3.858 & 0.706 & 7 & High & $\begin{array}{l}\text { The company uses special platforms for teaching and training } \\
\text { nanotechnology on the Internet. }\end{array}$ & 4 \\
\hline 3.888 & 0.772 & 4 & High & $\begin{array}{l}\text { The company has interns to acquire a career in } \\
\text { nanotechnology. }\end{array}$ & 5 \\
\hline 3.851 & 0.854 & 8 & High & $\begin{array}{l}\text { The company stimulates its members to education, training } \\
\text { and continuous production of a new generation of researchers, } \\
\text { innovators and inventors. }\end{array}$ & 6 \\
\hline 3.873 & 0.740 & 6 & High & $\begin{array}{l}\text { The company encourages its members to participate in } \\
\text { programs and workshops held at home and abroad }\end{array}$ & 7 \\
\hline 3.963 & 0.871 & 2 & High & $\begin{array}{l}\text { The company provides the necessary infrastructure and the } \\
\text { development of laboratories, devices and networks to help the } \\
\text { application of nanotechnology }\end{array}$ & 8 \\
\hline 3.910 & 0.422 & & High & General measurement & \\
\hline
\end{tabular}

It is noted from the table that the general measurement of the preparation of a qualified work force is high with a general average of (3.910) and a standard deviation of (0.422). The paragraph (aware of the importance of the workforce in spreading and adapting nanotechnology) With a high relative importance, while the paragraph (the company stimulates its members to education, training and continuous to produce a new generation of researchers, innovators and inventors) ranked last with an average of (3.851) and a high relative importance. 


\subsection{The Presence of Distinguished Leaders}

Table 8. Statistical averages, standard deviations, and relative importance of the paragraphs of distinct leadership

\begin{tabular}{|c|c|c|c|c|c|}
\hline $\begin{array}{l}\text { Arithmetic } \\
\text { mean }\end{array}$ & $\begin{array}{l}\text { standard } \\
\text { deviation }\end{array}$ & Rank & $\begin{array}{l}\text { relative } \\
\text { importance }\end{array}$ & Paragraph & NO \\
\hline 4.015 & 0.725 & 2 & High & $\begin{array}{l}\text { The management of the company is concerned with } \\
\text { individuals who have the intellectual vision of } \\
\text { nanotechnology and are able to convince others of it. }\end{array}$ & 9 \\
\hline 4.007 & 0.761 & 3 & High & $\begin{array}{l}\text { The management of the company seeks to bring about change } \\
\text { for the better and continuously. }\end{array}$ & 10 \\
\hline 3.896 & 0.739 & 4 & High & $\begin{array}{l}\text { The management of the company adopts plans and strategies } \\
\text { aimed at preparing leaders capable of dealing with complex } \\
\text { situations and difficult circumstances surrounding the } \\
\text { company. }\end{array}$ & 11 \\
\hline 4.075 & 0.782 & 1 & High & $\begin{array}{l}\text { The company's management is committed to the ethical } \\
\text { values of nanotechnology. }\end{array}$ & 12 \\
\hline 3.716 & 0.837 & 5 & High & $\begin{array}{l}\text { The company has a base for culture, knowledge, innovation } \\
\text { and achievement. }\end{array}$ & 13 \\
\hline 3.701 & 0.859 & 6 & High & $\begin{array}{l}\text { The company is working on a generation of leaders with a } \\
\text { democratic ideology capable of pushing individuals to } \\
\text { change for the better. }\end{array}$ & 14 \\
\hline 3.902 & 0.490 & & High & General measurement & \\
\hline
\end{tabular}

From the table, we can see that the general measure of the presence of distinct leaders is high, with a general average of 3.902 and a standard deviation of 0.490 . The paragraph (the management of the company is committed to ethical values of nanotechnology) ranked first with an average of 4.075 and a high relative importance. Paragraph (The company works to prepare a leading generation with democratic thinking capable of pushing individuals to change for the better) at the last rank with an average of (3.701), with a high relative importance.

\subsection{The Sovereignty of the Culture of Knowledge and Achievement}

Table 9. arithmetic means, standard deviations, and relative importance of the terms of the culture of knowledge and achievement culture

\begin{tabular}{|c|c|c|c|c|c|}
\hline $\begin{array}{l}\text { Arithmetic } \\
\text { mean }\end{array}$ & $\begin{array}{l}\text { standard } \\
\text { deviation }\end{array}$ & Rank & $\begin{array}{l}\text { relative } \\
\text { importance }\end{array}$ & Paragraph & NO \\
\hline 3.619 & 0.764 & 7 & Medium & $\begin{array}{l}\text { The management of the company assesses its members } \\
\text { according to culture, creativity, and the ability to think and } \\
\text { execute the work efficiently and effectively. }\end{array}$ & 15 \\
\hline 3.642 & 0.760 & 6 & Medium & $\begin{array}{l}\text { The management of the company considers its members as } \\
\text { innovators. }\end{array}$ & 16 \\
\hline 3.649 & 0.788 & 5 & Medium & $\begin{array}{l}\text { The management of the company encourages its members to } \\
\text { cooperate and work together to generate ideas and } \\
\text { innovation and achieve common goals of their own. }\end{array}$ & 17 \\
\hline 3.672 & 0.793 & 4 & High & $\begin{array}{l}\text { The management of the company stimulates its members to } \\
\text { creativity, innovation and achievement. }\end{array}$ & 18 \\
\hline 3.970 & 0.925 & 3 & High & $\begin{array}{l}\text { The management of the company follows the method of } \\
\text { creative scientific thinking, especially with the new } \\
\text { employees in order to achieve the objectives of the company. }\end{array}$ & 19 \\
\hline 4.082 & 0.868 & 2 & High & $\begin{array}{l}\text { Decisions are made in the company according to the analysis } \\
\text { and scientific consultation and near the centers of } \\
\text { implementation of decision makers in the company. }\end{array}$ & 20 \\
\hline 4.179 & 0.908 & 1 & High & $\begin{array}{l}\text { The employees of the company are assigned to the jobs } \\
\text { according to their ability to innovate, and fulfill the } \\
\text { requirements of the job. }\end{array}$ & 21 \\
\hline 3.830 & 0.391 & 7 & High & General measurement & \\
\hline
\end{tabular}

The general measure of the culture of knowledge and achievement is high with a general average of (3.830) and a standard deviation of 0.391 . The paragraph (assigns the employees of the company according to their ability to innovate, and fulfill the requirements of the job) ranked first with an average of (4.179) And the importance of relative high, while the paragraph (evaluate the management of the company's members according to culture, creativity, ability to think and implement the work efficiently and effectively) ranked last with an average of (3.619), and a medium relative importance 


\subsection{Forming Supporting Organizations}

Table 10. The arithmetical averages, the standard deviations and the relative importance of the terms of formation of the supporting organizations

\begin{tabular}{|c|c|c|c|c|c|}
\hline $\begin{array}{l}\text { Arithmetic } \\
\text { mean }\end{array}$ & $\begin{array}{l}\text { standard } \\
\text { deviation }\end{array}$ & Rank & $\begin{array}{l}\text { relative } \\
\text { importance }\end{array}$ & Paragraph & NO \\
\hline 3.769 & 0.858 & 5 & High & $\begin{array}{l}\text { The company has plans and strategies aimed at establishing } \\
\text { specialized research centers for nanoscience and } \\
\text { nanotechnology in each country with common interests to adopt } \\
\text { the ideas of manufacturing research and development related } \\
\text { processes in the field of nanotechnology and technology. }\end{array}$ & 22 \\
\hline 4.037 & 0.879 & 3 & High & $\begin{array}{l}\text { The company cooperates with various government and private } \\
\text { entities to fund research projects and the development of } \\
\text { nanoscience and science. }\end{array}$ & 23 \\
\hline 3.881 & 0.893 & 4 & High & $\begin{array}{l}\text { The company seeks to establish partnerships with multiple } \\
\text { institutions that deal with innovation and innovation and helps } \\
\text { start-up companies transform research results into } \\
\text { nanotechnologies and industries. }\end{array}$ & 24 \\
\hline 4.149 & 0.897 & 1 & High & $\begin{array}{l}\text { The company has a website that meets companies and } \\
\text { institutions that want to use nanotechnology commercially, and } \\
\text { those that have the right to know such as research centers, } \\
\text { universities, companies, individuals and others. }\end{array}$ & 25 \\
\hline 3.701 & 0.814 & 7 & High & $\begin{array}{l}\text { The company cooperates with incubator companies, } \\
\text { surrounding industrial groups and research centers to transfer } \\
\text { nanotechnology. }\end{array}$ & 26 \\
\hline 3.731 & 0.860 & 6 & High & $\begin{array}{l}\text { The company has cooperation and partnership relations with } \\
\text { specialized institutes and centers in the training and education of } \\
\text { nanoscience and technology, and seeks to take advantage of the } \\
\text { possibilities and tools available in it. }\end{array}$ & 27 \\
\hline 4.090 & 0.836 & 2 & High & $\begin{array}{l}\text { The company's management consists of a team of scientists who } \\
\text { are strategic thinkers, nanotechnologists, researchers, industry } \\
\text { and business people who are given broad powers in strategy } \\
\text { management, funding research projects and transforming } \\
\text { modern nanotechnologies into developing projects. }\end{array}$ & 28 \\
\hline 3.908 & 0.491 & & High & General measurements & \\
\hline
\end{tabular}

\subsection{Corporate Reengineering}

Table 11. The arithmetical averages, standard deviations and the relative importance of the corporate reengineering paragraphs

\begin{tabular}{|c|c|c|c|c|c|}
\hline $\begin{array}{l}\text { Arithmetic } \\
\text { mean }\end{array}$ & $\begin{array}{l}\text { standard } \\
\text { deviation }\end{array}$ & Rank & $\begin{array}{l}\text { relative } \\
\text { importance }\end{array}$ & Paragraph & NO \\
\hline 3.731 & 0.851 & 7 & High & $\begin{array}{l}\text { The company sets its long-term goals and strategies } \\
\text { accurately and clearly. }\end{array}$ & 29 \\
\hline 3.925 & 0.947 & 6 & High & $\begin{array}{l}\text { The company has a new vision aimed at radically } \\
\text { changing its activities and business. }\end{array}$ & 30 \\
\hline 4.179 & 0.754 & 1 & High & $\begin{array}{l}\text { The company views nanotechnology as a major hub } \\
\text { for change. }\end{array}$ & 31 \\
\hline 4.112 & 0.810 & 3 & High & $\begin{array}{l}\text { The company designs new management processes in } \\
\text { line with nanotechnology trends. }\end{array}$ & 32 \\
\hline 4.052 & 0.920 & 5 & High & $\begin{array}{l}\text { The company is changing new concepts in } \\
\text { nanoscience and technology and training its } \\
\text { employees to reach global competitiveness. }\end{array}$ & 33 \\
\hline 4.104 & 0.797 & 4 & High & $\begin{array}{l}\text { The company focuses on innovative manufacturing } \\
\text { processes and aligning them with the company's } \\
\text { objectives. }\end{array}$ & 34 \\
\hline 4.134 & 0.865 & 2 & High & $\begin{array}{l}\text { The company focuses on value-added manufacturing } \\
\text { processes and marginal operations and analyzes them } \\
\text { as a service to their interests. }\end{array}$ & 35 \\
\hline 4.034 & 0.543 & 7 & High & General measurement & \\
\hline
\end{tabular}


we note from the table The general measurement of corporate reengineering is high, with a general average of (4.034) and a standard deviation of (0.543). The paragraph (the company considers nanotechnology as a major axis for change) is ranked first with an average (4.179), While the paragraph (the company sets its objectives and long-term strategies accurately and clearly) ranked last with an average of (3.731), with high relative importance. To compare the dimensions of nanotechnology, the following table was prepared:

Table 12. arithmetic mean, standard deviations and the relative importance of nanotechnology

\begin{tabular}{llllll}
\hline $\begin{array}{l}\text { Arithmetic } \\
\text { mean }\end{array}$ & $\begin{array}{l}\text { standard } \\
\text { deviation }\end{array}$ & Rank & $\begin{array}{l}\text { relative } \\
\text { importance }\end{array}$ & Paragraph & NO \\
\hline 3.910 & 0.422 & 2 & High & Prepare a qualified workforce & 1 \\
3.902 & 0.490 & 4 & High & The existence of objective leadership & 2 \\
3.830 & 0.391 & 5 & High & The culture of knowledge and achievement & 3 \\
3.908 & 0.491 & 3 & High & Formation of Supporting Organizations & 4 \\
4.034 & 0.543 & 1 & High & Corporate reengineering & 5 \\
$\mathbf{3 . 9 1 7}$ & $\mathbf{0 . 3 3 7}$ & & High & Nanotechnology & \\
\hline
\end{tabular}

The results of the table show that the level of nanotechnology in terms of relative importance is high, with an arithmetic mean (3.917) and a standard deviation (0.337). The table also showed that the company re-engineering ranked first with an average of 4.034 and a standard deviation of 0.543 ), With high relative importance, while (culture of knowledge and achievement culture) ranked last with an average of (3.830) and a standard deviation (0.391), with a high relative importance.

Second: Reduce costs

Table 13. arithmetic means, standard deviations and relative importance of cost reduction clauses

\begin{tabular}{|c|c|c|c|c|c|}
\hline $\begin{array}{l}\text { Arithmetic } \\
\text { mean }\end{array}$ & $\begin{array}{l}\text { standard } \\
\text { deviation }\end{array}$ & Rank & $\begin{array}{l}\text { relative } \\
\text { importance }\end{array}$ & Paragraph & NO \\
\hline 4.134 & 0.821 & 3 & High & $\begin{array}{l}\text { The company's leading management adopts all methods and } \\
\text { strategies to reduce the costs of its activities and operations. }\end{array}$ & 36 \\
\hline 3.918 & 0.850 & 8 & High & $\begin{array}{l}\text { The company's cost system is efficient and effective in terms } \\
\text { of real-time costing of products. }\end{array}$ & 37 \\
\hline 3.933 & 0.833 & 7 & High & $\begin{array}{l}\text { The company's costing system is capable of measuring the } \\
\text { actual performance of the components and components of the } \\
\text { product and the production process. }\end{array}$ & 38 \\
\hline 4.097 & 0.793 & 5 & High & $\begin{array}{l}\text { The company's management focuses on reducing its costs } \\
\text { while maintaining the quality of its products. }\end{array}$ & 39 \\
\hline 3.761 & 0.806 & 10 & High & $\begin{array}{l}\text { The company's management takes all effective methods and } \\
\text { means to limit the production of defective and contravening } \\
\text { products. }\end{array}$ & 40 \\
\hline 3.828 & 0.809 & 9 & High & $\begin{array}{l}\text { The company's management focuses on monitoring and } \\
\text { evaluating the performance of the planned plans and } \\
\text { comparing their actual costs with what is planned for the pilot. }\end{array}$ & 41 \\
\hline 4.246 & 0.642 & 1 & High & $\begin{array}{l}\text { The Company's management adopts all methods and } \\
\text { strategies to improve value-added activities and processes and } \\
\text { to reduce the volume of non-value-added activities and } \\
\text { processes. }\end{array}$ & 42 \\
\hline 4.142 & 0.727 & 4 & High & Reducing costs is one of the company's strategic objectives. & 43 \\
\hline 4.082 & 0.868 & 6 & High & $\begin{array}{l}\text { The Company's management conducts a continuous review of } \\
\text { the costs of activities, products and operations. }\end{array}$ & 44 \\
\hline 3.679 & 0.711 & 11 & High & $\begin{array}{l}\text { The management of the company takes into consideration the } \\
\text { views and suggestions of experts and specialists concerned } \\
\text { with the application of cost reduction methods. }\end{array}$ & 45 \\
\hline 4.149 & 0.818 & 2 & High & $\begin{array}{l}\text { The company holds programs and training workshops for } \\
\text { various administrative levels to raise the level of productivity } \\
\text { and reduce errors and deviations in the work to achieve } \\
\text { manufacturing leadership. }\end{array}$ & 46 \\
\hline 3.997 & 0.370 & & High & General measurement & \\
\hline
\end{tabular}

we note from the table that the general measurement of cost reduction is high, with a general average of (3.997) and a standard deviation of (0.370). The paragraph (the company's management adopts all methods and strategies aimed at improving value-added activities and processes and reducing the volume of non-host activities and operations) (4.246) and the relative importance of high, while the paragraph (taking the management of the company taking into account the views and suggestions of experts and specialists involved in the application of methods to reduce the cost) was at the last rank with an average (3.679), and a high relative importance 


\section{Testing Hypotheses}

The main hypothesis of the study was tested using multiple regression analysis. The results of the hypothesis test are presented below.

Results of the hypothesis of the main study hypothesis H0: There is no statistically significant effect of the application of nanotechnology on the reduction of production costs in the Jordanian industrial companies.

Table 14. Testing the impact of applying nanotechnology on cost reduction

\begin{tabular}{lllllll}
\hline Form summary & & & $\begin{array}{l}\text { Analysis } \\
\text { ANOVA }\end{array}$ & of & variance & The dependent variable \\
\cline { 1 - 5 } Coefficient R & $\begin{array}{l}\text { Selection } \\
\text { Factor } \mathbf{R}^{\mathbf{2}}\end{array}$ & Adjusted $\mathbf{R}^{\mathbf{2}}$ & $\begin{array}{l}\text { Calculated } \\
\text { value }\end{array}$ & $\mathbf{F}$ & Sig $(\mathbf{F})$ & \\
\hline 0.733 & 0.537 & 0.519 & 29.732 & 0.000 & Costs reduction \\
\hline
\end{tabular}

The value of the correlation coefficient $(\mathrm{R}=0.733)$ was found to be less than 0.05 and the mean value of $(\mathrm{F}=$ 29.732) $(\mathrm{R} 2=0.537)$ indicates that $53.7 \%$ of the variation in (cost reduction) can be explained by the variation in (application of the dimensions of nanotechnology) combined, with the remaining factors staying fixed.

Therefore, we reject the main hypothesis of the study of , and accept the alternative which is stated:

"There is a statistically significant impact on the application of nanotechnology to reduce production costs in Jordanian industrial companies"

Table 15. Regression coefficient of the impact of nanotechnology dimensions on cost reduction

\begin{tabular}{|c|c|c|c|c|c|}
\hline \multicolumn{5}{|l|}{ Regression coefficients } & \multirow{2}{*}{ VIF } \\
\hline Independent variables & coefficients (B) & Standard error & Calculated $\mathrm{T}$ value & Sig (T) & \\
\hline Prepare a qualified workforce & 0.342 & 0.079 & 4.314 & 0.000 & 1.657 \\
\hline $\begin{array}{l}\text { The presence of distinguished } \\
\text { leaders }\end{array}$ & 0.010 & 0.058 & 0.177 & 0.860 & 1.406 \\
\hline $\begin{array}{l}\text { The prevailing of the culture of } \\
\text { knowledge and achievement }\end{array}$ & 0.292 & 0.074 & 3.950 & 0.000 & 1.777 \\
\hline $\begin{array}{l}\text { Formation of } \\
\text { Organizations }\end{array}$ & 0.093 & 0.052 & 1.778 & 0.078 & 1.282 \\
\hline Corporate reengineering & 0.145 & 0.044 & 3.325 & 0.001 & 1.147 \\
\hline Gradient Constant & 0.506 & 0.305 & 1.656 & 0.100 & \\
\hline
\end{tabular}

The results of the first hypothesis test H01: There is no effect to the development of a qualified workforce to reduce production costs in Jordanian industrial companies

From the table above, we note that the regression coefficients indicated that the value of the coefficient at (qualified labor force) was $(\mathrm{B}=0.342)$, a significant effect, where the t value is $(4.144)$ and the significance level $($ Sig $=0.000)$ We therefore reject the first hypothesis, and accept the alternative which states that:"There is an impact to the development of a qualified workforce to reduce production costs in Jordanian industrial companies"

The results of the second hypothesis test H02: There is no effect of the presence of distinguished leaders on the reduction of production costs in the Jordanian industrial companies, From the table above, we note that the regression coefficients indicated that the value of the coefficient at the presence of distinct leaders reached $(\mathrm{B}=$ 0.010 ), which is insignificant, where the value of $\mathrm{t}$ is 0.177 and the level of significance is $(\mathrm{Sig}=0.860$ ) We therefore accept the second hypothesis, which states that: "There is no impact of the presence of distinguished leaders to reduce production costs in the Jordanian industrial companies"

The results of the third hypothesis test H03: There is no impact of the prevailing of culture of knowledge and achievement on reducing production costs in the Jordanian industrial companies

From the table above, we note that the regression coefficients indicated that the value of the coefficient at (prevailing of the culture of knowledge and achievement) was $(B=0.292)$, which is significant, where the $t$ value is $(3.950)$ and the significance level $(\mathrm{Sig}=0.000)$ We therefore reject the third hypothesis, and accept the alternative which states that:

"There is an impact on the sovereignty of knowledge and achievement culture on reducing production costs in Jordanian industrial companies"

The results of the fourth hypothesis test H04: There is no impact of the formation of supporting organizations on the reduction of production costs in the Jordanian industrial companies

From the table above, we observe that the regression coefficients indicated that the value of the coefficient at the formation of the supporting organizations was $(\mathrm{B}=0.093)$, which is insignificant, where the $\mathrm{t}$ value is $(1.778)$ and the significance level $(\mathrm{Sig}=0.078)$ We accept the fourth hypothesis, which states that: 
"There is no impact of the formation of supporting organizations on the reduction of production costs in the Jordanian industrial companies"

The results of the fifth hypothesis test H05: There is no impact of re-engineering companies on reducing production costs in Jordanian industrial companies

From the table above, we note that regression coefficients indicated that the value of the coefficient at (re-engineering companies) reached $(\mathrm{B}=0.145)$, which is significant, where the value of $\mathrm{t}$ is $(3.325)$ and the level of significance ( $\mathrm{Sig}=0.001)$ We reject the fifth hypothesis, and accept the alternative which states that:

"The impact of re-engineering companies on reducing production costs in Jordanian industrial companies"

To determine which of the dimensions of nanotechnology has had the most significant impact in reducing costs, the stepwise regression analysis has been carried out. The results were as follows:

Table 16. Results of the regression analysis of the main hypothesis

\begin{tabular}{|c|c|c|c|c|c|c|c|}
\hline B & $\begin{array}{l}\text { Calculated } \\
\text { t value }\end{array}$ & $\begin{array}{l}\text { Sig* } \\
\text { Level of } \\
\text { significance }\end{array}$ & $\begin{array}{l}\mathbf{R}^{2} \\
\text { The coefficient } \\
\text { of determination }\end{array}$ & $\begin{array}{l}\text { Calculated } \\
\text { F }\end{array}$ & $\begin{array}{l}\text { Sig* } \\
\text { Level of } \\
\text { significance }\end{array}$ & Costs reduction & $\begin{array}{l}\text { The } \\
\text { model }\end{array}$ \\
\hline 0.572 & 9.101 & 0.000 & 0.386 & 82.825 & 0.000 & $\begin{array}{l}\text { The prevailing of the } \\
\text { culture of knowledge } \\
\text { and achievement }\end{array}$ & $1^{\mathrm{st}}$ \\
\hline 0.379 & 5.468 & 0.000 & 0.486 & 61.850 & 0.000 & $\begin{array}{l}\text { The prevailing of } \\
\text { culture of knowledge } \\
\text { and achievement }\end{array}$ & $2^{\text {nd }}$ \\
\hline 0.389 & 5.050 & 0.000 & & & & $\begin{array}{l}\text { Prepare a qualified } \\
\text { workforce }\end{array}$ & \\
\hline 0.340 & 5.014 & 0.000 & & & & $\begin{array}{l}\text { The prevailing of the } \\
\text { culture of knowledge } \\
\text { and achievement }\end{array}$ & 3 rd \\
\hline 0.348 & 4.621 & 0.000 & 0.526 & 48.027 & 0.000 & $\begin{array}{l}\text { Prepare a qualified } \\
\text { workforce }\end{array}$ & \\
\hline 0.144 & 3.312 & 0.001 & & & & $\begin{array}{l}\text { Reengineering } \\
\text { companies }\end{array}$ & \\
\hline
\end{tabular}

* The effect is statistically significant at $\alpha(0.05)$

The results of the regression analysis show the order of the variables in the regression model. The effect of the application of nanotechnology is the reduction of costs. It was found that the prevailing of the culture of knowledge and achievement was ranked first and 38.6 percent of the variance in the dependent variable was explained. (48.6\%). The interpretation rate increased to $(52.6 \%)$ when re-engineering the companies. The effect of the variables was found to have a significant effect at a lower level of significance From 0.001. Both the existence of distinct leaderships and the formation of supporting organizations have been excluded due to the lack of moral influence in each.

\section{Results}

1. The significance of the (application of nanotechnology dimensions) combined to (cost reduction) where the value of $(\mathrm{F}=29.732)$ and the level of significance $(\mathrm{SigF}=0.000)$ is less than 0.05 , and the correlation coefficient value $(\mathrm{R}=0.733)(\mathrm{R} 2=0.537)$ indicates that $53.7 \%$ of the variation in (cost reduction) can be explained by the variation in (application of the dimensions of nanotechnology) combined, with any other factors remaining Fixed.

2. There is an impact to developing a qualified workforce to reduce production costs in the Jordanian industrial companies

3. There is no trace of the existence of distinguished leaders to reduce production costs in the Jordanian industrial companies "

4. There is an impact of the sovereignty of the culture of knowledge and achievement on reducing production costs in Jordanian industrial companies "

5. There is no trace of the formation of supporting organizations on reducing production costs in the Jordanian industrial companies "

6. There is an impact of re-engineering companies on reducing production costs in Jordanian industrial companies"

7. The results of the regression analysis show the order of entry of the variables in the regression model which is the effect of the application of nanotechnology on the reduction of costs. It was found that the culture of knowledge and achievement was ranked first and justified the $38.6 \%$ of the variance in the dependent variable (cost reduction). 
And after adding the dimension (developing a qualified work force) in the second module, the justification percentage was increased to reach $(48.6 \%)$. The interpretation rate increased to $(52.6 \%)$ when (re-engineering the companies) was added. The effect of the variables was also significant at the level of Significance less than 0.001. Both the existence of distinct leaderships and the formation of supporting organizations have been excluded due to the absence of a significant impact to each of them.

\section{Recommendations}

1. The Jordanian Industrial Company's management should adopt all methods and strategies to improve value-added activities and processes and reduce the volume of non-value-added activities and processes to reduce manufacturing costs.

2. Industrial companies should consider nanotechnology as a major hub for industrial structural changes.

3. Pioneering industrial companies have a website that meets companies and institutions wishing to use nanotechnology commercially, and those that have the right to know such as research centers, universities, companies, individuals and others.

4. The departments of industrial companies to assign the employees of the company to jobs according to their ability to innovate and achieve and their suitability for the job requirements.

5. The necessity of the Jordanian Industrial Department to adhere to the ethical values of nanotechnology to reach the industrial and local industrial leadership.

6. The need of the management of industrial companies and decision makers to recognize the importance of the workforce in the deployment and adaptation of nanotechnology to reach the industrial world.

\section{References}

Ahmeda, M. H. S., Ahmida, N. H. S., \& Ahmeida, A. A. (2017). Introduction to nanotechnology: definition, terms, occurrence and applications in environment", 2(1), 12-26

Al-Baqi, F. (2008). Focus on the design phase in determining the target costs of production at the cost limits charged. Tikrit Magazine for Administration and Economic Sciences, 4(12), Tikrit, Iraq, 159-178.

Alexandra, M. S. (2010). Nanotechnology for tomorrow the best series of world editions Kuwait filtered knowledge. The Economic Importance of Nanotechnology Economic and Administrative, 92(22), 400-414

Arnold, J., Tony, R., Chapman, N. S., \& Clive, M. L. (2008) Introduction of materials management. 6th, Ed. Person Parentice-Hall.

Ashmawi, M. A. F. (2011). Cost accounting: traditional and modern perspectives. (I 1), Amman: Dar Al Yazuri Scientific Publishing and Distribution.

Askarany, D., \& Yazdifar, H. (2007). Why ABC is Not Widely Implemented? International Journal of Business, $7(1)$.

Aziz, B. S. M. (2006). The Use of value engineering and reengineering processes in Cost demotion: An applied study in the General Company for Electrical Industries. PHD thesis (not published), University of Salahaddin, Erbil, Iraq.

Baird, K., Harrison, G., \& Reeve, R. (2007). Success of activity management practices: the influence of organizational and cultural factors. Accounting \& Finance, 47(1), 47-67. https://doi.org/10.1111/j.1467-629X.2006.00195.X

Benelmekki, M. (2015). "An introduction to nanoparticles and nanotechnology", Designing Hybrid Nanoparticles, chapter 1, page 1-14.

Cooper, R., \& Kaplan, R. S. (1988). Measure costs right: make the right decisions. Harvard Business Review, 66(5), 96-103.

Erekat, S. M. A. (2015). Impact of Quality Control on Cost Reduction: An Empirical Study On food companies in the Hashemite Kingdom of Jordan. Unpublished Master Thesis, Middle East University, Amman, Jordan.

Fadzil, F. H. B., \& Rababah, A. (2012). Management Accounting Change: ABC Adoption and Implementation. Journal of Accounting and Auditing: Research \& Practice, 2012, 1-17. https://doi.org/10.5171/2012.349927

Fouda, S. (2007). A proposed framework for the integration of the target cost method with the strategic cost analysis to reduce the costs of activities through the value chain concept: a theoretical and exploratory study.(1), Alexandria University, pp. 187-253. 
Goetsch, D. L., \& Davis, S. B. (2006). Quality management introduction to total quality management for production, processing and services, (5 ed.). New Jersey: Pearson Prentice Hall.

Hadidi, H. R. (2006). The strategy to manage the cost reduction target Applied by the General Company for Pharmaceutical Industry and Medical Supplies. Unpublished MA, University of Mosul, Mosul, Iraq.

Horngren, C., Foster, G., \& Datar, S. (2016). Cost Accounting: Managerial Emphasis. 17th ed., Prentice - Hall International, New Jersey, INC, USA.

Najjar, Y. M. A. (2007). Application of ABC - based costing system The Jordanian Industrial Sector, its Justifications and Its Components: A Field Study. master's thesis (not published) Amman Arab University, Amman, Jordan.

Paddock, C. (2012, May 4). “Nanotechnology In Medicine: Huge Potential, But What Are The Risks?” Medical News Today. Retrieved from https://www.medicalnewstoday.com/articles/244972.php

Rahamna, N. M. A. N. (2011). Impact of the cost-based accounting system In Reducing Costs and Evaluating Prices in Jordanian Joint Stock Companies: A Field Study. Unpublished MA, Applied Science University, Amman, Jordan.

Rajakhan, M. M. M. (2002). The role of cost targets in reducing costs and developing Products: Field study on industrial projects in Jeddah. Master Thesis (UnPublished), King Abdulaziz University, jeddah, KSA

Saini, R., Saini, S., \& Sharma, S. (2010). Nanotechnology: The future medicine, 3(1), 32-33.

Saleh, W. K. (2012). Role of costs based on activities in implementing Competitive strategies Anbar University Journal of Economic and Administrative Sciences, 4(8), Anbar, Iraq, 293-316.

Satalkar, P., Elger, B. S., Shaw, D. M. (2016). "Defining Nano, Nanotechnology and Nanomedicine: Why Should It Matter?” Sci Eng Ethics. 2016 Oct; 22(5), 1255-1276. https://doi.org/10.1007/s11948-015-9705-6

Sulaiman, G. A. A., Sultan, I. S., \& Amin, O. A. Q. H. (2012). scale down Costs using the process reengineering approach: an applied study at the University of Sulaymaniyah. Anbar University Journal of Economic and Administrative Sciences, 4(9), 345-372.

\section{Copyrights}

Copyright for this article is retained by the author(s), with first publication rights granted to the journal.

This is an open-access article distributed under the terms and conditions of the Creative Commons Attribution license (http://creativecommons.org/licenses/by/4.0/). 